\title{
Preliminary Findings in the Cartographic Uncertainty Depiction of the Arctic in European Renaissance Maps
}

\author{
Danai-Maria Kontou \\ Durham University, UK
}

Keywords: Arctic maps, Renaissance maps, Uncertainty Visualisation, Cartographic Uncertainty

\begin{abstract}
:
The Arctic, a not yet explored region in the $15^{\text {th }}-17^{\text {th }}$ centuries, however it is present in European map-makers' historical maps of the Renaissance era (approximately 1450-1650). The Polar Regions were the last ones to be explored and therefore was an open space for the cartographic imagination to thrive (Wheeler 2009; Mulvaney 2001; Lewis Jones 2017). This paper discusses the preliminary findings of the author's archival research on the depiction and classification of uncertainty in the Arctic via a selection of ten European Renaissance maps. In maps, especially the historical ones, the uncertainty is the product of lack of data (Jurado, Ludvigson, and Ng 2015; Bammer and Smithson 2008; Monmonier 2006; Bradley and Drechsler 2014; Kinkeldey, MacEachren, and Schiewe 2014; MacEachren 1992); today, uncertainty may occur due to poor measurements (measurement uncertainty), perspective (translational uncertainty), temporality (temporal uncertainty), and complexity (structural uncertainty) (Rowe 1994), even if there is a massive amount of data for remote and challenging access areas such as the Arctic (Couclelis 2003).
\end{abstract}

Uncertainty, is a privative term, that means it is defined by the lack of something else, certainty in this case. So, what is certainty? Deriving from the Latin word certus, certainty is a synonym of sureness and certitude, describing facts or truths unquestionably established. Uncertainty can appear in any form and field in geography, from analysing and explaining spatial phenomena to geographic definitions and planning and risk management (Fusco et al. 2017; Monmonier 2006; Brown 2004; Zhang 2019). Moreover, uncertainty might be caused by ignorance (Bammer and Smithson 2008). That ignorance is depicted in Renaissance maps by the creation and illustration of imaginary lands, and mythical beasts and the fading or aggregated coastlines.

Based on a review of the literature of Renaissance Cartography, it is concluded that there are three main categories of cartographic elements showing uncertainty: (1) fading or schematic coastlines, (2) beasts and mythical creatures presence, and (3) imaginary places (Van Duzer 2013; Wintle 1999; Woodward 2007). Even if the spatial representations of the whole earth in the studied period were called "Cosmographies" and of regions "Chorographies", for the sake of practicality and general understanding is used "Cartography" is used in this paper (Woodward 2007). The cartographic timeline starts with Fra Mauro's map of the world in 1450. The high Arctic is placed at the bottom of the map, including the North Pole. The timeline finishes with the Collage of World maps and Geographical Diagrams by Giuseppe Rosaccio in 1610 . 


\section{Uncertainty Depiction of the Arctic in European Renaissance Maps}

\begin{tabular}{|c|c|c|c|c|}
\hline & & 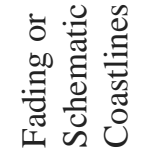 & 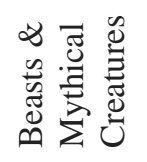 & 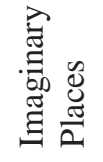 \\
\hline 1450 & $\begin{array}{l}\text { Fra Mauro, } \\
\text { Mappa Mundi } \\
\text { This map marks the period } \\
\text { between the Medieval and } \\
\text { Renaissance European Maps. Its } \\
\text { purpose was to visualise the } \\
\text { "world" or, with today's terms, the } \\
\text { "until then known world". Fra } \\
\text { Mauro based his cosmography on } \\
\text { Portolan maps and expeditions' } \\
\text { descriptions. For the time created, } \\
\text { this map uniqueness is its } \\
\text { orientation, which has the Arctic } \\
\text { at the bottom of the map. }\end{array}$ & & & \\
\hline 1536 & $\begin{array}{l}\text { Olof Månsson, } \\
\text { Carta Marina } \\
\text { Carta Marina is the first map of } \\
\text { the Nordic Countries with details } \\
\text { on places and names, made by the } \\
\text { Swedish Månsson. This pictorial } \\
\text { map was in production for } 11 \text { and } \\
\text { a half years. Among the } \\
\text { illustrations of many beasts, } \\
\text { mythical creatures and imaginary } \\
\text { lands, there are illustrations of } \\
\text { towns, castles, mines, and } \\
\text { woodlands. The gothic } \\
\text { chorography was firstly made in } \\
\text { woodcut and later on copperplate } \\
\text { engraving by Antonio Lafteri in } \\
\text { Rome } 1572 \text {. }\end{array}$ & & & \\
\hline
\end{tabular}




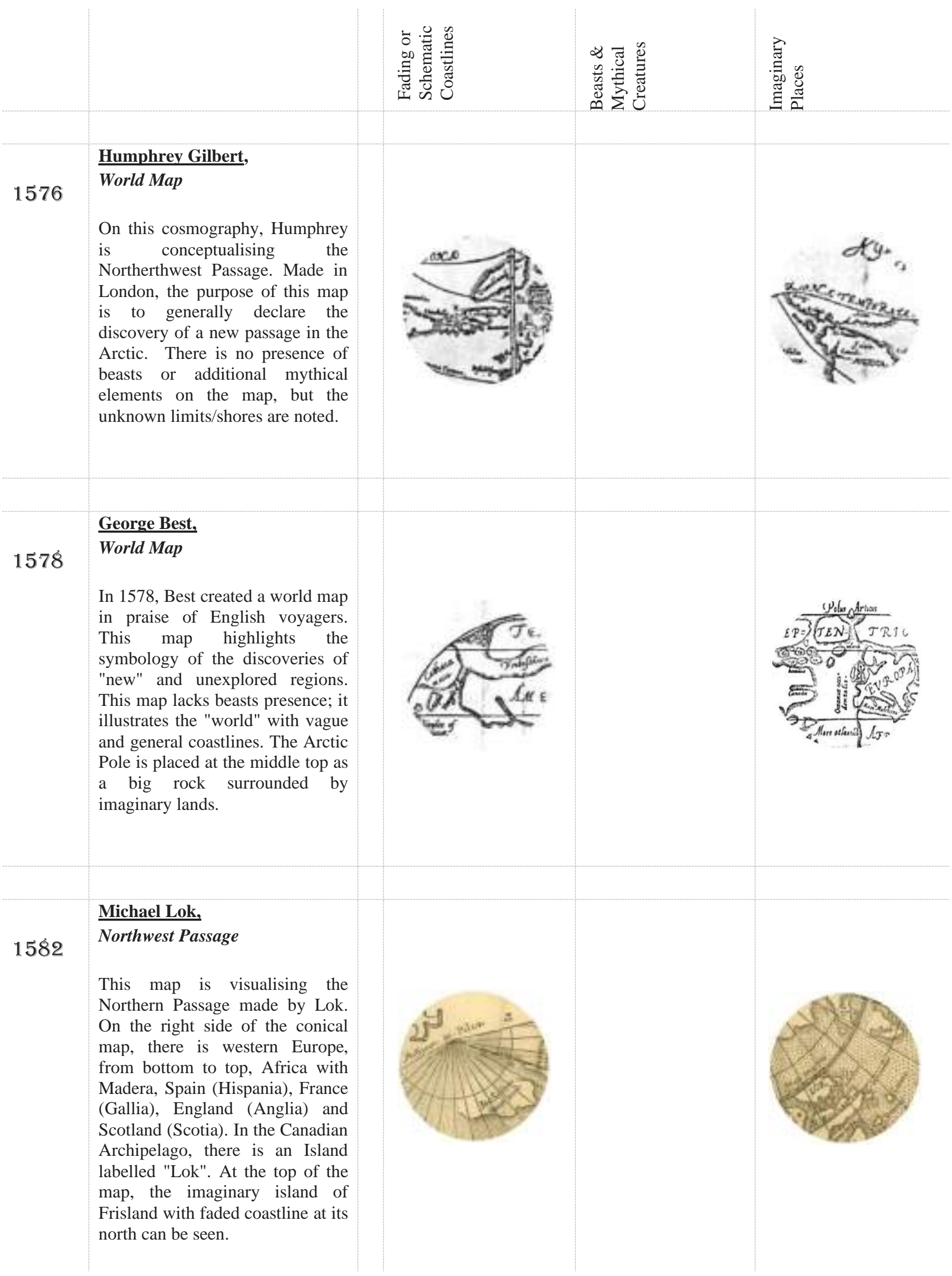




\section{Gerard Mercator, Map of the Arctic}

The Arctic map by Mercator is part of the first world Atlas, made by him. There might be no illustrations of beasts, but there are descriptions of the Lands of the Pygmei, mythical short humans. The four islands surrounding the -rock- Arctic Pole are not the only imaginary lands on the map. The mythical island of Frisland is located in the upper left corner of the map.

\section{John Blagrave, \\ Polar Stereographic}

Blagrave used the North Polar Stereographic projection to the equator, with the south being shrunk at the corners. There are two big ships illustrated on this map; one at the Atlantic Ocean, and the other at the Pacific Ocean. Both beasts and faded coastlines are present on this map. At the north pole a compass rose is located.

\section{Willem Barentsz, Polar Region}

This Arctic Map by the Dutch navigator and cartographer is based on his third -and lastvoyage in the Arctic, Barentsz discovered Spitsbergen, which is illustrated with a faded coastline towards its unexplored side. The highly decorated map with sea beasts leave the North Pole area empty and places a big rock close to Anian straights (today called "Bering Strait") labeled as "Magnetic Pole". Barentzs died during this expedition.

In in
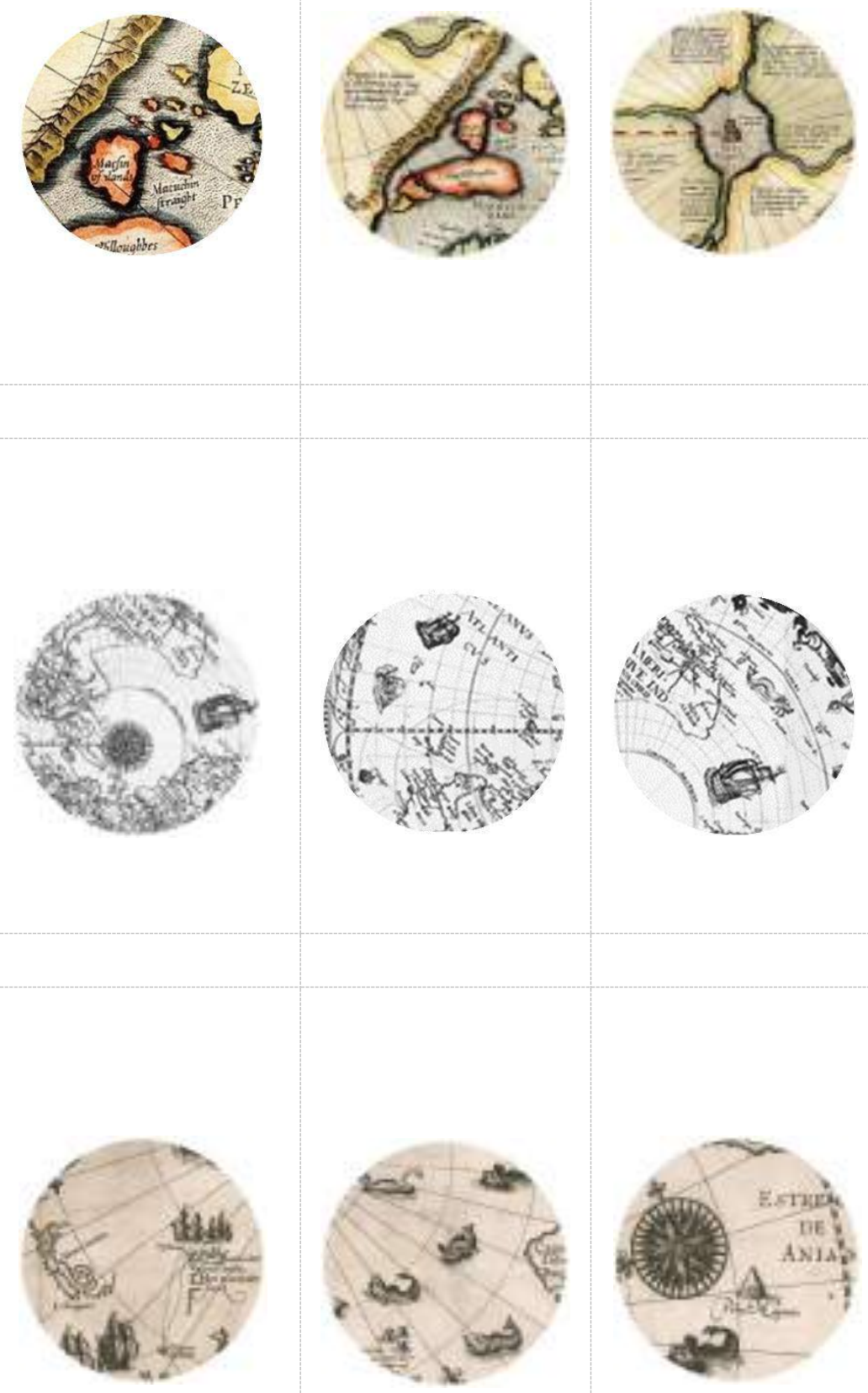


\section{Edward Wright,}

World Map

One of the earliest world charts using Mercator's projection was by Edward Wright, a mathematician and cartographer in 1599. The map/chart depicts the "known" world; its purpose is navigational. In the Arctic, there is present the fading of the coastlines at the yet unexplored areas.

\section{Giuseppe Rosaccio,} Collage of World Maps

The Florentine physician and scholar Giuseppe Rossario created a geographical collage in 1610 . Against the Ptolemaic world, Rosaccio depicts the world in two hemispheres, reflecting the discoveries of the $15^{\text {th }}$ and $16^{\text {th }}$ centuries. Celebrating modernity in Cartography the collage is dedicated to Cosimo II de'Medici, a Duke of the House of Medici, the family which funded the Medici bank and produced four Popes of the Catholic Church. The collage is decorated with coats of arms of the Medici family and contains explanatory images such as a legend in the left bottom corner, the Aristotelian concept of the elements and the Ptolemaic calculation of the earth's circumference.
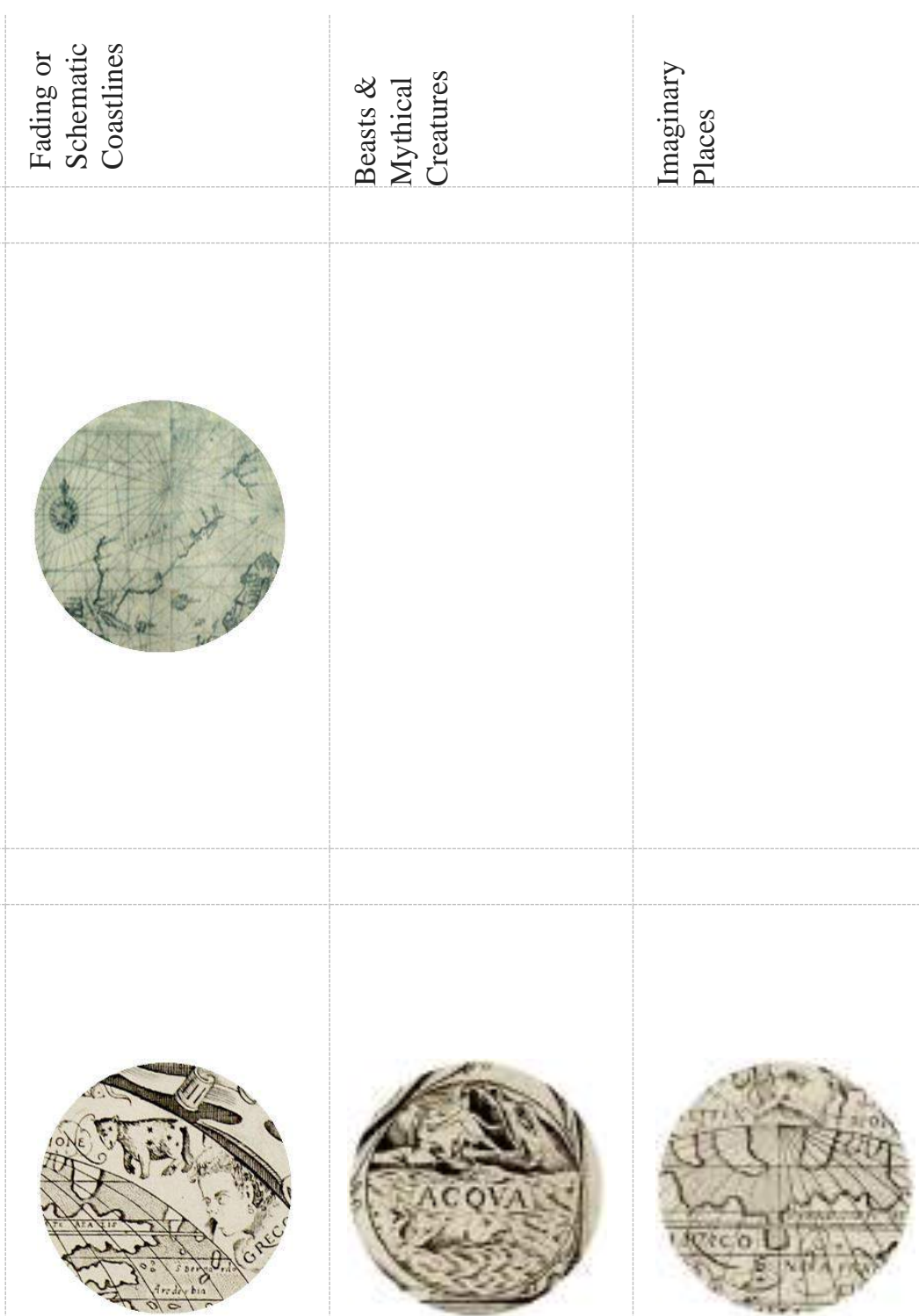


\section{Map Appendix:}

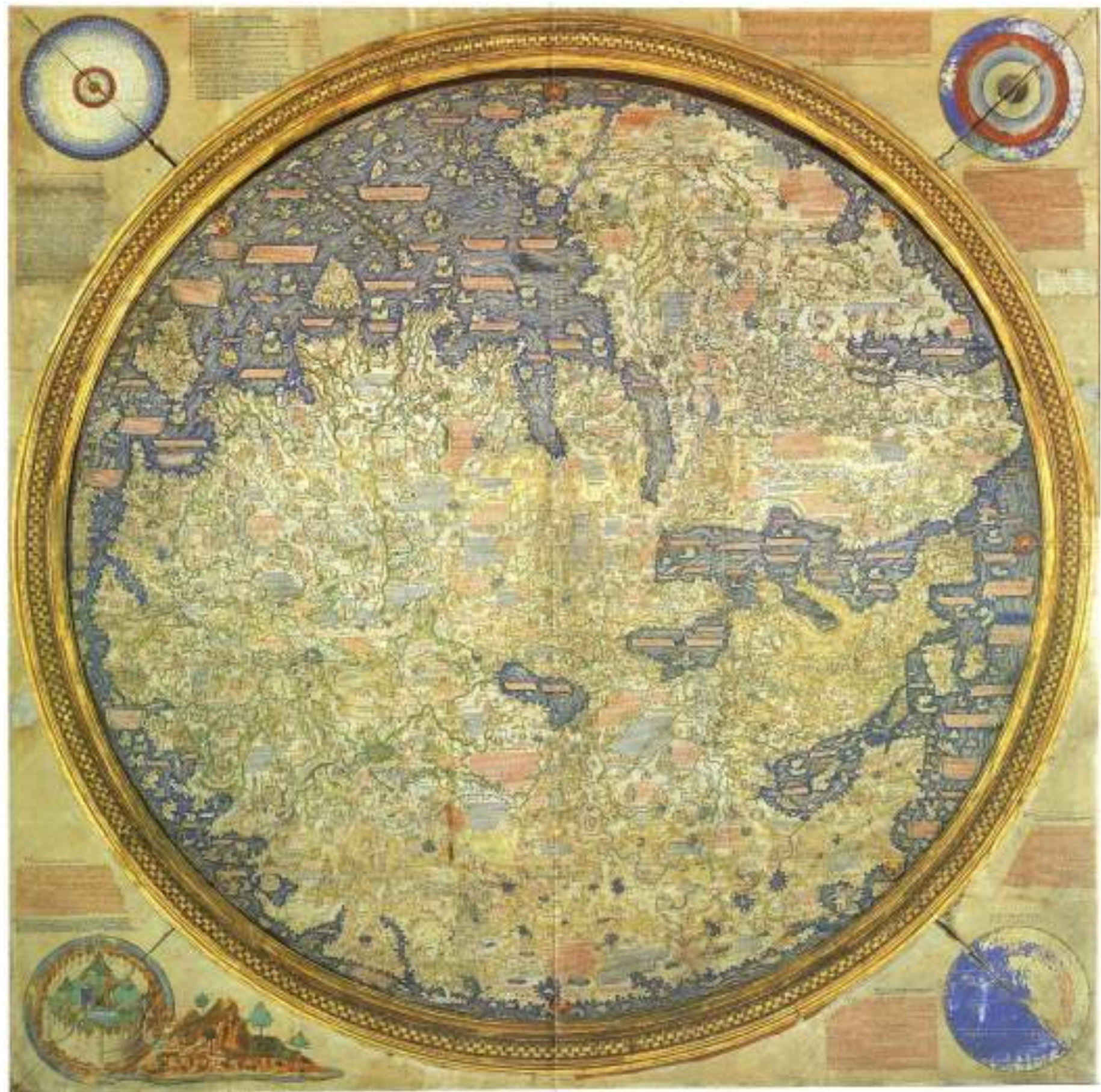

Figure 1 World Map by Fra Mauro, 1450 -public domain- 


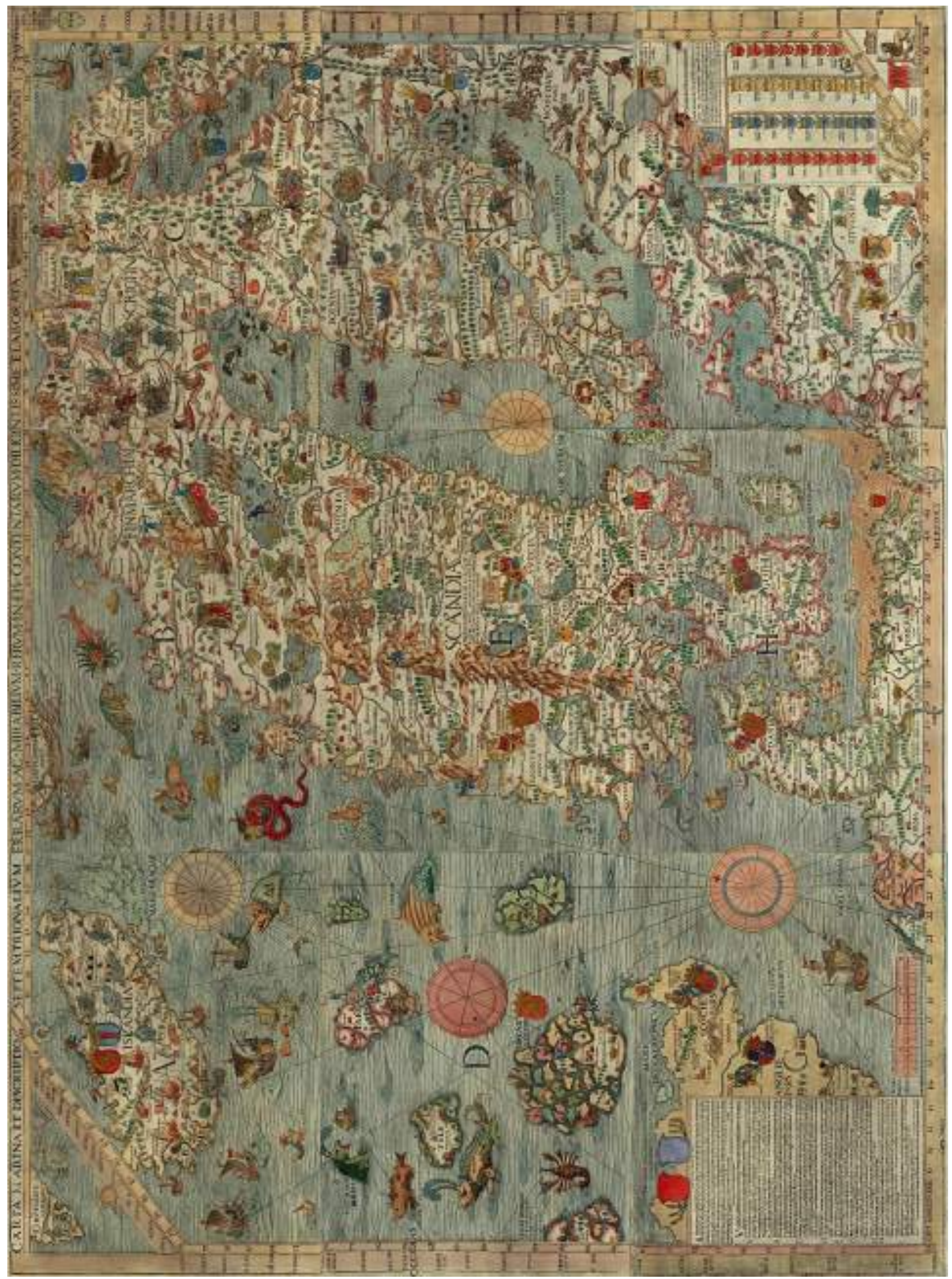

Figure 2 Carta Marina by Olof Månsson, 1539 -public domain-

Abstracts of the International Cartographic Association, 3, 2021.

30th International Cartographic Conference (ICC 2021), 14-18 December 2021, Florence, Italy.

https://doi.org/10.5194/ica-abs-3-156-2021 | @ Author(s) 2021. CC BY 4.0 License. 


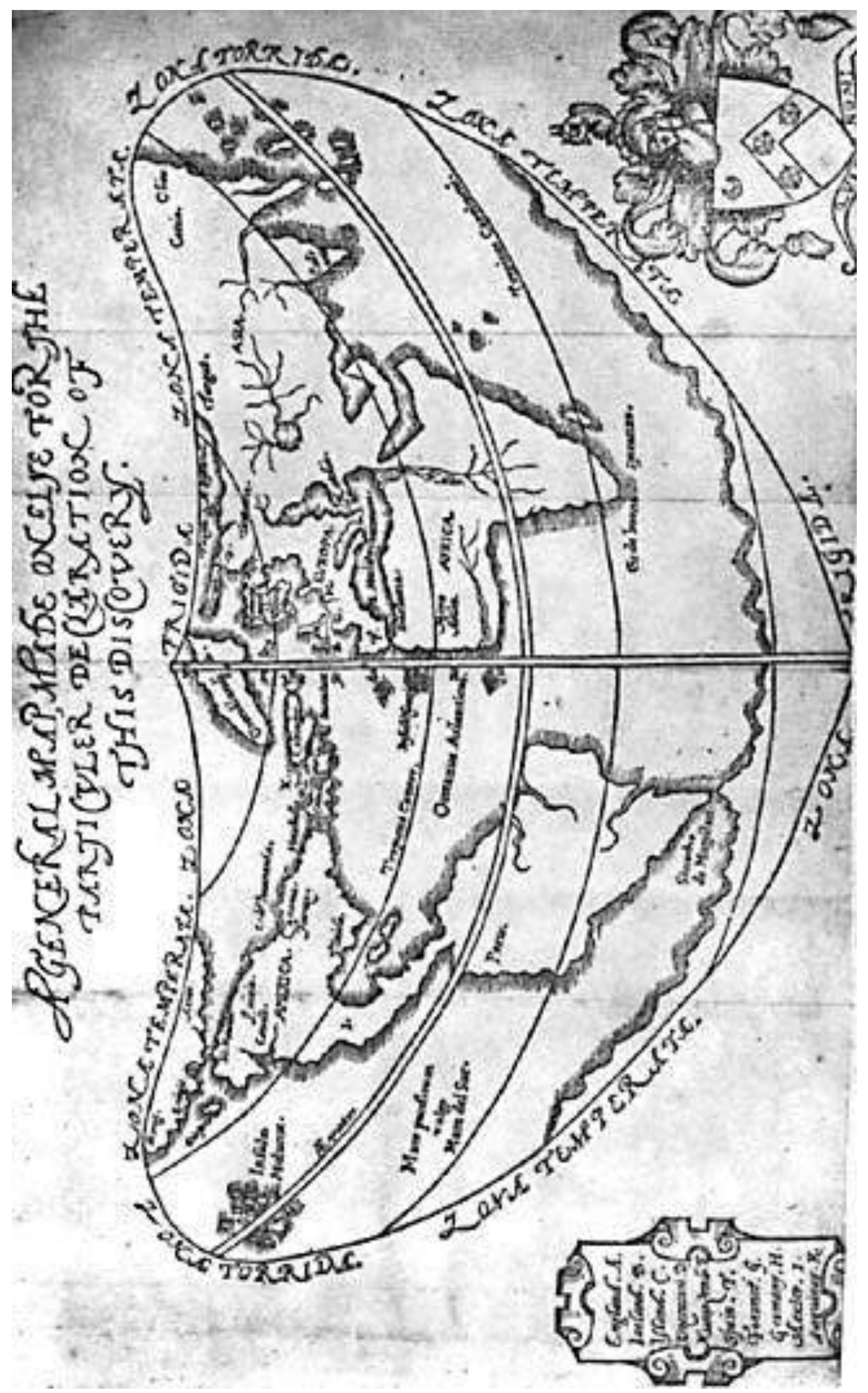

Figure 3 World Map conceptualising the Northwest Passage by Humphrey Gilbert, 1576 -public domain- 


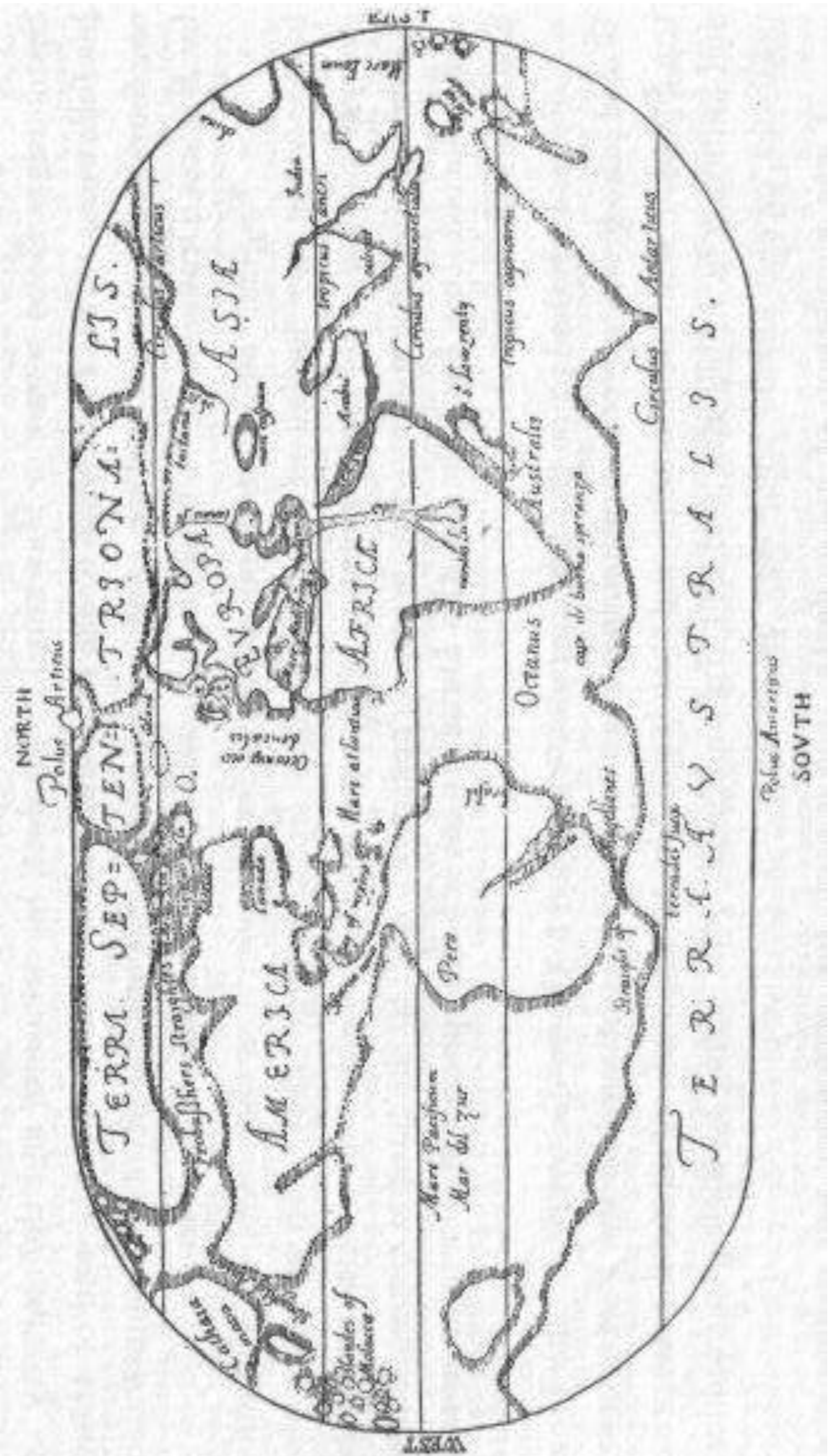

Figure 4 World Map in Praise of English Voyages by George Best, 1578 -public domain-

Abstracts of the International Cartographic Association, 3, 2021. 


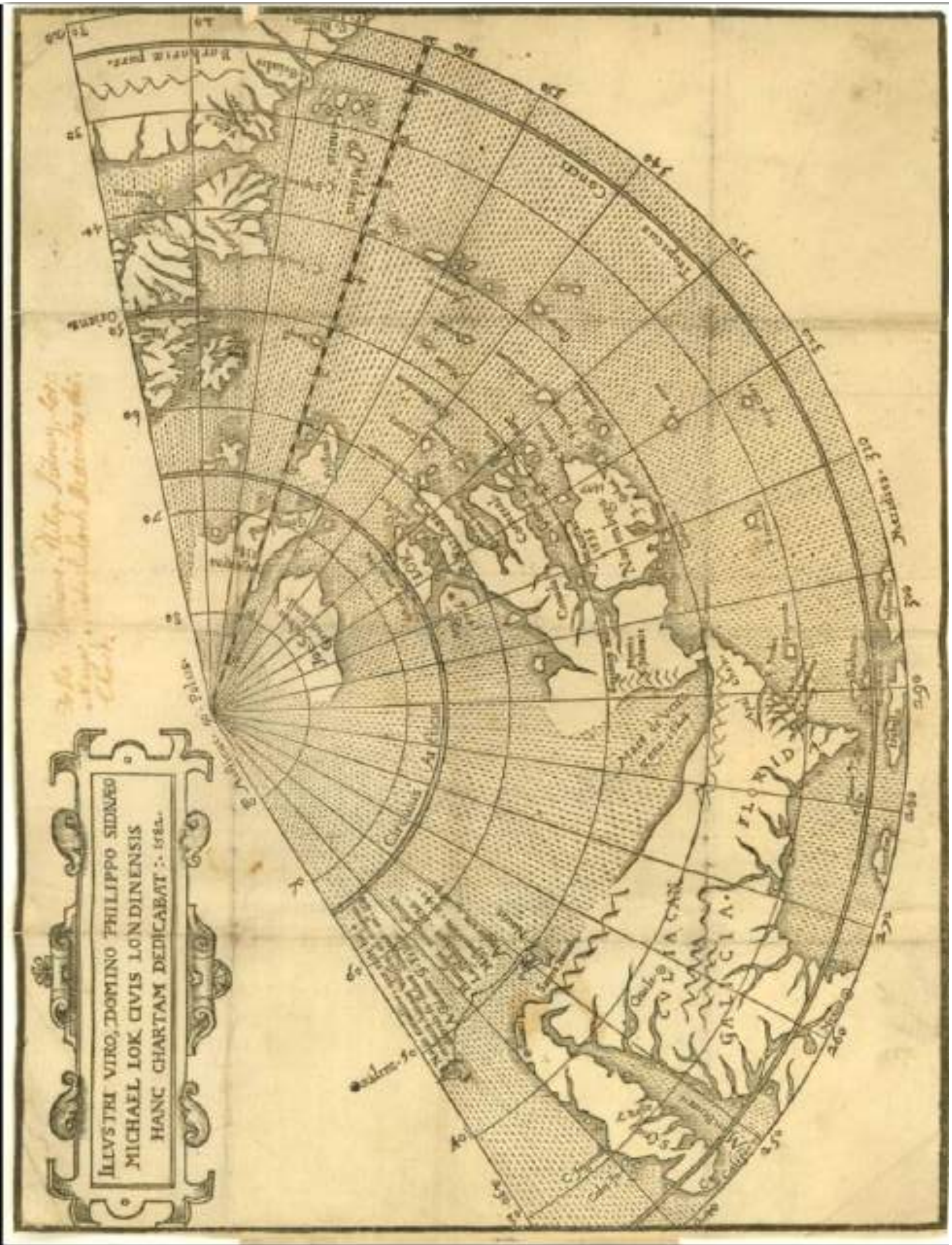

Figure 5 Map of the Northwest Passage by Michael Lok, 1582 -public domain- 


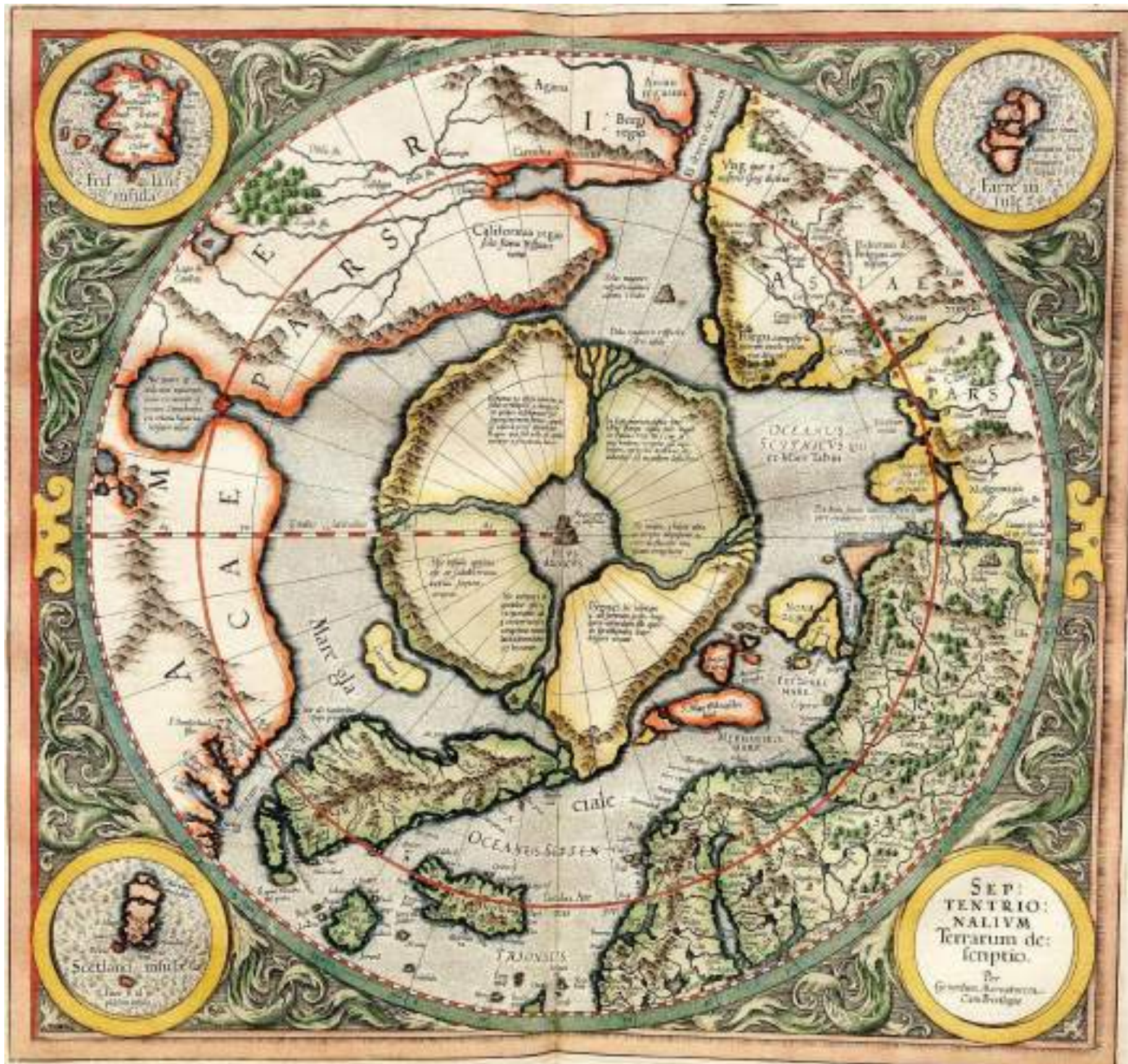

Figure 6 Map of the Arctic by Gerard Mercator, 1595 -public domain- 


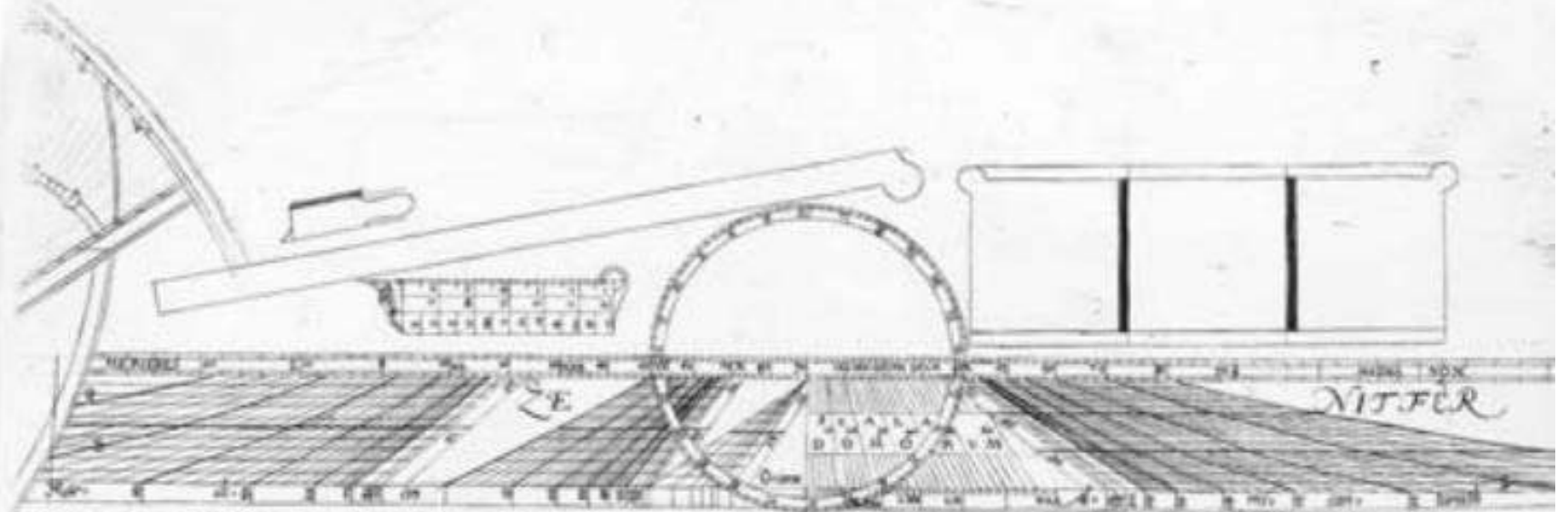

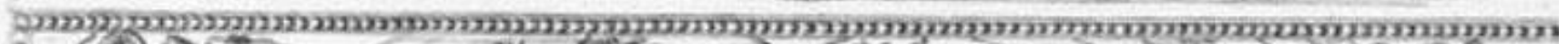

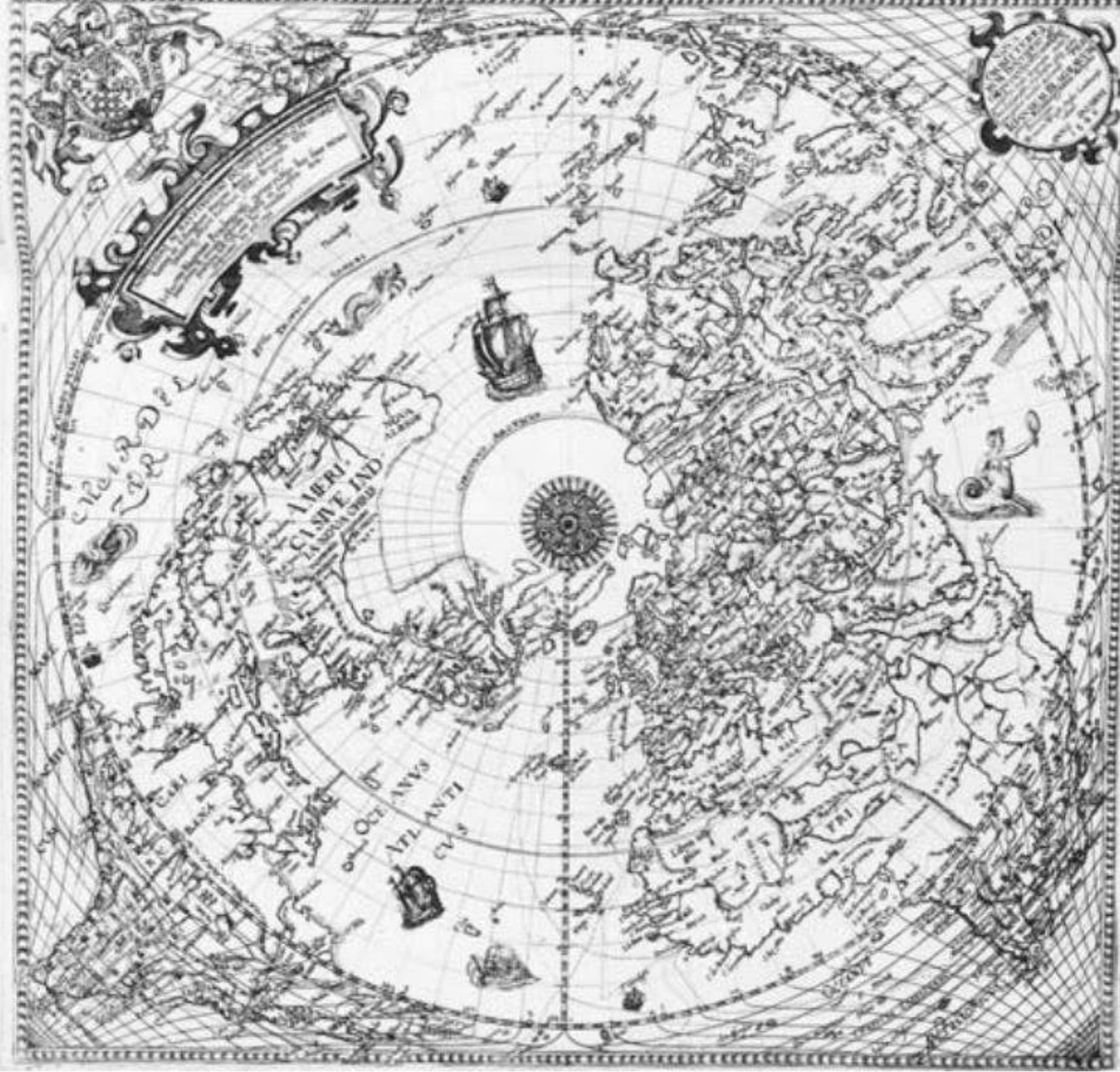

Figure 7 Polar Stereographic Projection by John Blagrave, 1596 -public domain- 


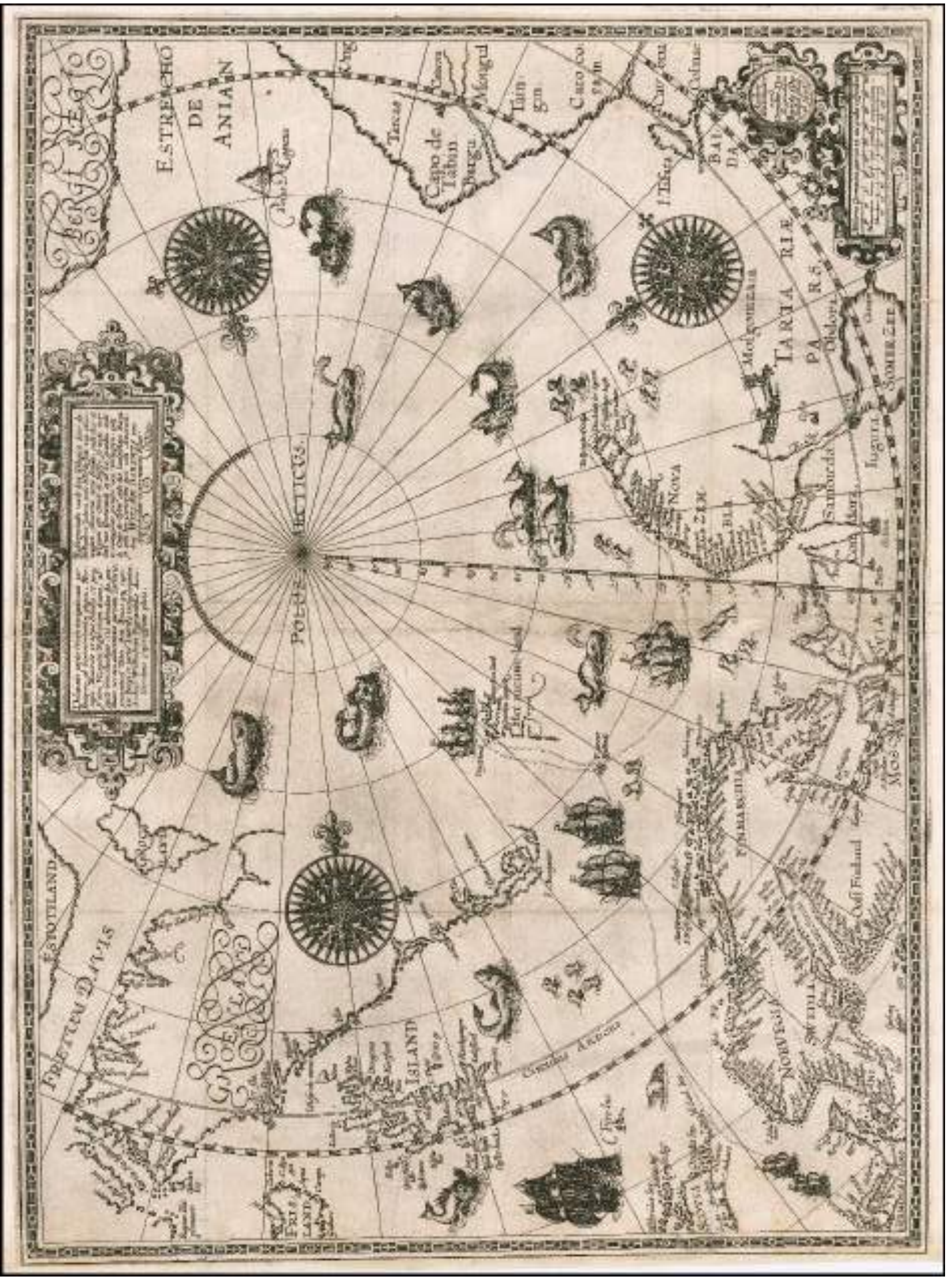

Figure 8 Map of the Polar Region by Willem Barentsz, 1598 -public domain- 


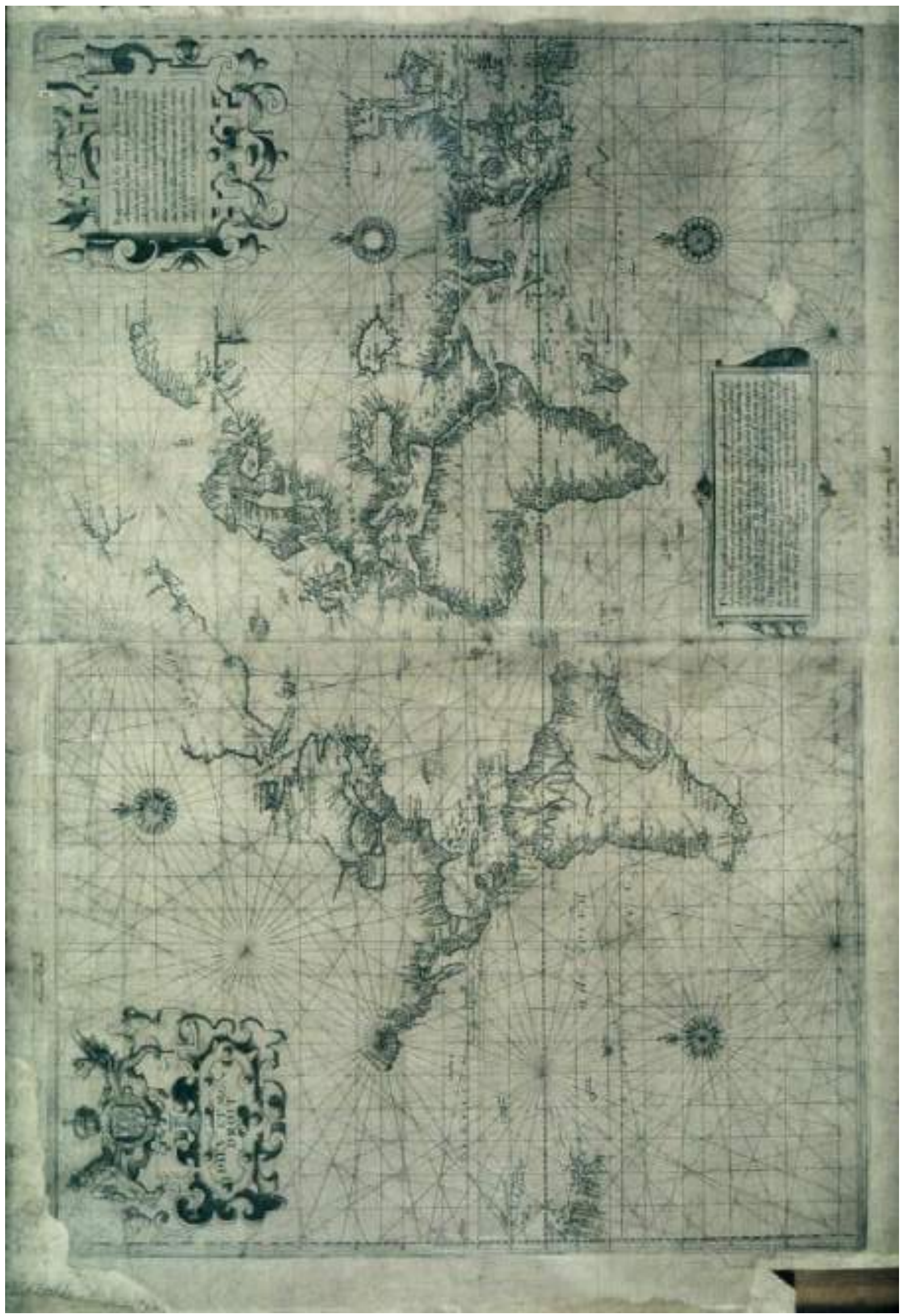

Figure 9 World Map on Mercator's Projection by Edward Wright, 1599 -public domain-

Abstracts of the International Cartographic Association, 3, 2021.

30th International Cartographic Conference (ICC 2021), 14-18 December 2021, Florence, Italy. https://doi.org/10.5194/ica-abs-3-156-2021 | @ Author(s) 2021. CC BY 4.0 License. 


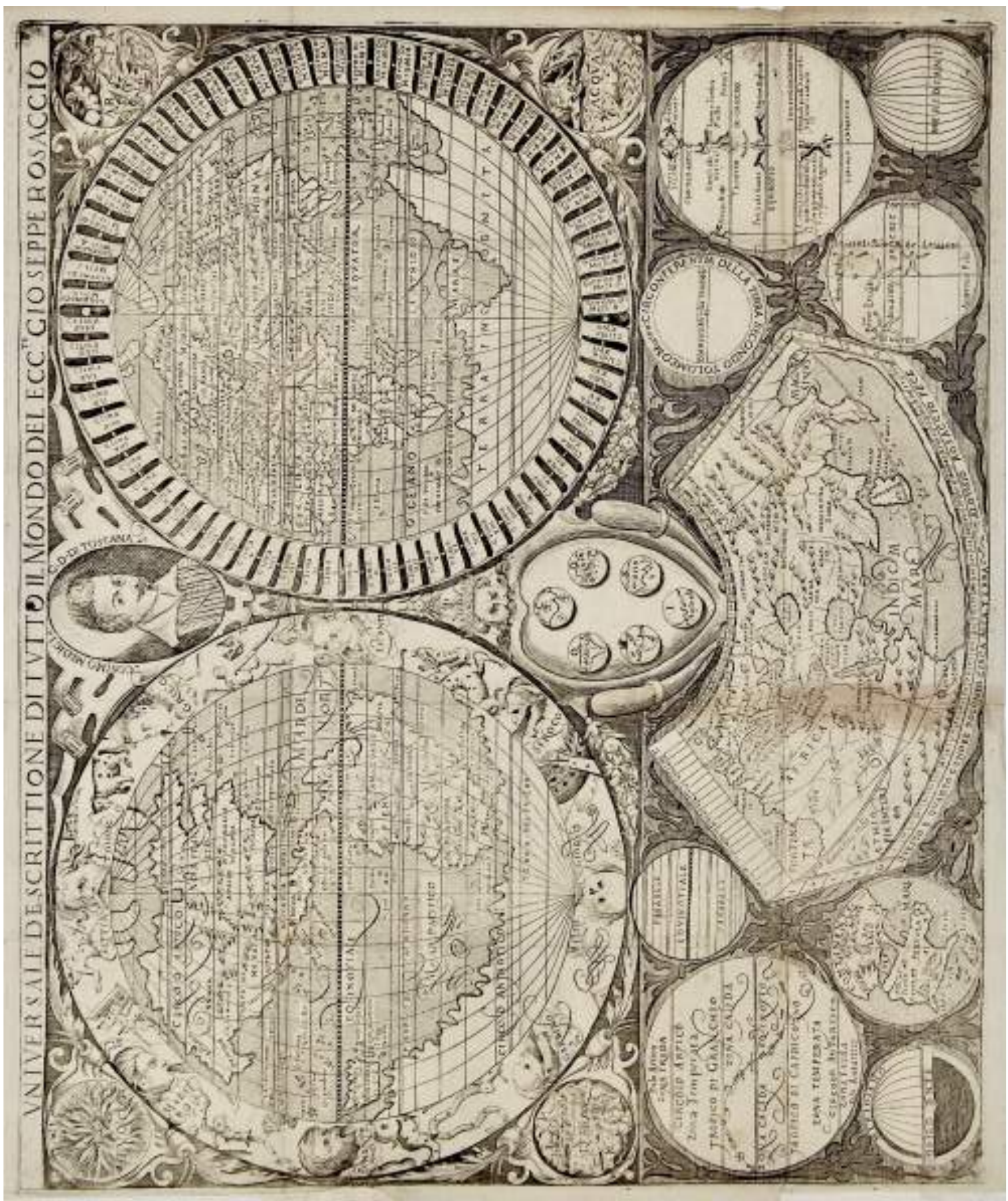

Figure 10 Collage of World Maps by Giuseppe Rosaccio, 1610 -public domain- 


\section{Selective Bibliography:}

Bammer, Gabriele, and Michael Smithson. 2008. 'Understanding Uncertainty’, Interaction Insights, , no. 7: 8.

Bradley, Richard, and Mareile Drechsler. 2014. 'Types of Uncertainty'. Erkenntnis 79 (6): 1225-48. https://doi.org/10.1007/s10670-013-9518-4.

Brown, James D. 2004. 'Knowledge, Uncertainty and Physical Geography: Towards the Development of Methodologies for Questioning Belief'. Transactions of the Institute of British Geographers 29 (3): 367-81. https://doi.org/10.1111/j.0020-2754.2004.00342.x.

Couclelis, Helen. 2003. 'The Certainty of Uncertainty: GIS and the Limits of Geographic Knowledge'. Transactions in GIS 7 (2): 165-75. https://doi.org/10.1111/1467-9671.00138.

Fusco, Giovanni, Matteo Caglioni, Karine Emsellem, Myriam Merad, Diego Moreno, and Christine Voiron-Canicio. 2017. 'Questions of Uncertainty in Geography'. Environment and Planning A: Economy and Space 49 (10): 2261-80. https://doi.org/10.1177/0308518X17718838.

Jurado, Kyle, Sydney C. Ludvigson, and Serena Ng. 2015. 'Measuring Uncertainty'. American Economic Review 105 (3): 1177-1216. https://doi.org/10.1257/aer.20131193.

Kinkeldey, Christoph, Alan M. MacEachren, and Jochen Schiewe. 2014. 'How to Assess Visual Communication of Uncertainty? A Systematic Review of Geospatial Uncertainty Visualisation User Studies'. The Cartographic Journal 51 (4): 372-86. https://doi.org/10.1179/1743277414Y.0000000099.

Lewis Jones, Huw. 2017. Imagining the Arctic: Heroism, Spectacle and Polar Exploration\$Huw Lewis-Jones. Tauris Historical Geography Series 9. London New York: I.B. Tauris.

MacEachren, Alan M. 1992. 'Visualizing Uncertain Information'. Cartographic Perspectives, no. 13 (June): $10-19$. https://doi.org/10.14714/CP13.1000.

Monmonier, Mark. 2006. 'Cartography: Uncertainty, Interventions, and Dynamic Display'. Progress in Human Geography 30 (3): 373-81. https://doi.org/10.1191/0309132506ph612pr.

Mulvaney, Kieran. 2001. At the Ends of the Earth: A History of the Polar Regions. Washington, DC: Island Press/Shearwater Books.

Rowe, William D. 1994. 'Understanding Uncertainty'. Risk Analysis 14 (5): 743-50. https://doi.org/10.1111/j.15396924.1994.tb00284.x.

Van Duzer, Chet. 2013. Sea Monsters on Medieval and Renaissance Maps. London: The British Library.

Wheeler, Sara. 2009. The Magnetic North: Notes from the Arctic Circle. London: Jonathan Cape.

Wintle, Michael. 1999. 'Renaissance Maps and the Construction of the Idea of Europe'. Journal of Historical Geography 25 (2): 137-65. https://doi.org/10.1006/jhge.1999.0111.

Woodward, David. 2007. Cartography in the European Renaissance. Vol. 3. 3 vols. The History of Cartography, v. 3, pts $1 \&$ 2. Chicago: University of Chicago Press.

Zhang, Jingxiong. 2019. Uncertainty in Geographical Information. Place of publication not identified: CRC Press. 